\title{
Calculation Models for Average Stress and Plastic Deformation Zone Size of Bonding Area in Dentine Bonding Systems
}

\author{
Kunio WAKASA, Masao YAMAKI and Akira MATSUI ${ }^{1}$ \\ Department of Dental Materials, Hiroshima University School of Dentistry, \\ Kasumi 1 chome, Minamiku, Hiroshima City, 734 Japan \\ ${ }^{1}$ AOI Dental Center, Oike-kudaru, Fuyamachi, Nakagyouku, Kyoto, 604 Japan
}

Received July 21, 1995/Accepted October 27, 1995

\begin{abstract}
Average stress during shear bond testing, and deformation behaviour during nano-indentation testing were calculated for the bonding area as a bonding site for copolymerization with resin composite in dentine bonding systems. First, average stress was calculated in the bonding area between bovine dentine and composite resin. Secondly, the plastic deformation zone size was calculated using an elastic/plastic deformation zone model after a nano-indentation test. The result clearly showed that average stress depended upon the elasticity of the bonding area, the elasticity value ratio of the composite resin-to-bonding area, and interfacial stress between the dentine and the adhesive resin. In this bonding area, the elasticity/hardness ratio changed depending on the thickness of the bonding area as well as the plastic deformation zone size (b), expressed as a (b/2a)-value (indented triangular length (2a) at nano-indentation test) expanded with increasing the elasticity value.
\end{abstract}

Key words : Bond strength, Adhesive resin, Bonding agent

\section{INTRODUCTION}

In previous studies, bonding between dentine and restorative composite resin was evaluated in terms of adhesive bond strength value ${ }^{1-6)}$, and variation in bond strength values was explained by the hypothesis that failure was due to cohesive fracture of dentine because the bond between adhesive resin and the dentine exceeded the cohesive strength of the dentine itself. Bond strength varied with dentine depth (superficial, intermediate, and deep dentine $)^{6}$. Nakabayashi et al. ${ }^{7,8)}$ reported that the 4-META/MMA-TBB system formed tenacious bonds to enamel or dentine, and a hybrid layer mechanism was proposed as the cause of dentine adhesion. Bond strength increased dramatically when true hybridization occurred because of a resin-impregnated zone ${ }^{8)}$. An interdiffusion zone between dentine and composite resin was examined morphologically ${ }^{9}$. After etching and priming with different dentine bonding systems, the bonding site for copolymerization with the resin composite is considered the bonding area. The bonding area has been represented schematically in terms of its morphological aspects in dentine bonding systems ${ }^{2,8,9)}$. Analytical models are thus needed to calculate average stress and nano-indentation behaviours of the bonding area on the hybrid layer, as we indicated schematically in an earlier report ${ }^{10)}$. Conditioning with an acidic agent demineralized the dentine surface to a certain depth and left behind a collagenrich mesh-work ${ }^{11}$. Bonding monomers altered, as predicted, the collagen-fibre arrangement in a way that facilitated the penetration of an adhesive bonding monomer. Nakabayashi $e t$ 
$a l .{ }^{8)}$ and Van Meerbeek et al..$^{9)}$ found an adhesive resin layer (bonding area) in the resinimpregnated layer (hybrid layer). The studies on stress distribution in the dentine bonding area showed the following results. Van Noort et $a l .{ }^{12)}$, using finite element stress analysis, found that nonuniform stress acted upon the bonded interface using finite element stress analysis. Wakasa and Yamaki reported that maximum principal stress occurred along the dentine/adhesive resin interface in the bonding area during uniform tensile testing ${ }^{13)}$. Interfacial failure might be promoted when critical stress acts in the formation (initiation and propagation) of cracks $^{5,14,15)}$.

The present study examined shear bond strength and bonding area thickness by shear bond testing and bonding area hardness by nano-indentation testing, and attempted to determine theoretically a) the average strength value along the dentine/bonding interface in the bonding area, and b) the plastic deformation zone size based on elasticity and hardness values of the bonding area, using analytical calculation models. The bonding area was defined as the bonding site of adhesive resin for the copolymerization on the hybrid layer.

\section{MATERIALS AND METHODS}

The dentine bonding systems used in this study are coded $\mathrm{A}^{*}, \mathrm{~B}^{* *}, \mathrm{C}^{\#}, \mathrm{D}^{\#}, \mathrm{E}^{\circledR}$ and $\mathrm{F}^{\circledR}$ for the shear bonding test and the nano-indentation test. The bonding steps of the experimental treatments are listed according to Pashley et al. ${ }^{6}{ }^{6}$ and Van Meerbeek et al. ${ }^{9)}$ snotation, partly modified for the materials used in this study. $a=$ apply conditioner, $b=$ rinse conditioner, $c=$ air dry, $\mathrm{d}=$ apply primer, $\mathrm{e}=$ cure primer, $\mathrm{f}=$ apply resin, $\mathrm{g}=$ thin resin with air, $\mathrm{h}=$ visible light cure, $\mathrm{i}=$ chemical cure, $\mathrm{j}=$ apply low viscosity resin, cure, $\mathrm{k}=$ apply composite. The dentine bonding sequences were dcfhk (5 steps) for code A, abcdcfghk (9 steps) for B, abcdcfgijhk (11 steps) for C, abcdcfhk (8 steps) for D, abcdefick (9 steps) for E, and abcdfgck ( 8 steps) for F. Bonding was performed on bovine dentine whose sites were polished with \#600 emery paper. The bonding area was limited by the use of double-sided adhesive tape containing a $6 \mathrm{~mm}$ diameter hole. A $6 \times 6 \mathrm{~mm}$ cylindrical nylon matrix was placed on the treated surface. Visible light-cured resins $\left(A 1^{\$}\right.$ for code $A, B 1^{\$ \$}$ for code $B, C 1+$ for code $C$, $\mathrm{D}^{++}$for code $\mathrm{D}$, and $\mathrm{C} 1$ for code $\mathrm{E}$ and $\mathrm{F}$ ) were placed in two $1.5 \mathrm{~mm}$ increments by photocuring for $60 \mathrm{~s}$. Between 45 and $60 \mathrm{~min}$ after bond, shear bond strength was tested to failure at a crosshead speed of $0.5 \mathrm{~mm} / \mathrm{min}$. Ten specimens were prepared for the shear bond strength test (kilograms were divided by the surface area of the bond and then

* Imperva Bond, Shofu Inc, Kyoto, Japan

** Light Bond, Tokuyama Co, Tokuyama City, Yamaguchi, Japan

\# Clearfil Liner Bond, Kuraray Co, Okayama, Japan

\# Scotchbond Multipurpose, 3M Co, St. Paul, MN, USA

(a) Superbond D-liner Plus, Sun Medical Co, Kyoto, Japan

@ @ Gluma Bonding System, Bayer Dental, Germany

$\$$ Occulsin, ICI Co, UK

\$ Graft LCII, Shofu Inc, Kyoto, Japan

+ Clearfil Photo Posterior, Kuraray Co, Okayama, Japan

+ Z-100, 3M Co, St. Paul, MN, USA 
converted to $\mathrm{MPa}$ ) ${ }^{\&}$ and a nano-indentation test\&\&. A schematic presentation of the operation of the nano-indenter has been detailed ${ }^{16)}$. Prior to measurement of nano-indentation behaviour, the indentation position was checked by optical microscopy (X 500 magnification), and the load was precisely indented to the bonding area. The indentation was performed with a nano-indenter with a small load of $6 \mathrm{mN}$. The thickness of the bonding area was measured using a scanning electron microscope . $^{\text {. }}$

\section{Calculation models}

Fig. 1 shows a schematic diagram on $\mathrm{x}-\mathrm{y}$ coordinates of a calculation model employing bonding area thickness $(\mathrm{d})$, diameter of bonding area $(\ell)$ and height of samples including composite resin (D). In Van Noort et al. ${ }^{12)}$, shear stress direction along the top of the surface of a sample was schematically indicated as a test arrangement, where a twodimensional plane strain section was assumed. Following to this assumption, the schematic diagram in Fig. 1 was used in this study to average stress along the interface between dentine and adhesive resin. The procedure to calculate average stress is described in Appendix 1 and the stress value is calculated according to the equation (I), where each displacement of bonding area (adhesive resin) and composite resin is denoted by $d_{u}$, and $d_{v}$. In Appendix 1 , the applied strain $(e)$ was assumed to be located along $\mathrm{x}$-axis.

Fig. 2 shows schematic diagrams for estimation of plastic deformation zone size (b) and indentation length (2a) for the elastic/plastic deformation zone based on nano-indentation testing on the principal axes of the 1- and 2- (indented plane), and 3- directions (indentation direction). The internal stress which occurred after nano-indentation was evaluated on the assumption that indented volumetric change produced uniform eigenstrain $\varepsilon_{33} *$ only along the indentation direction but the others $\left(\varepsilon_{11} *\right.$ and $\left.\varepsilon_{22}{ }^{*}\right)$ were zero; eigenstrain related to internal stress effects was described originally by Mori and Tanaka ${ }^{17)}$. Fundamentally, it is assumed

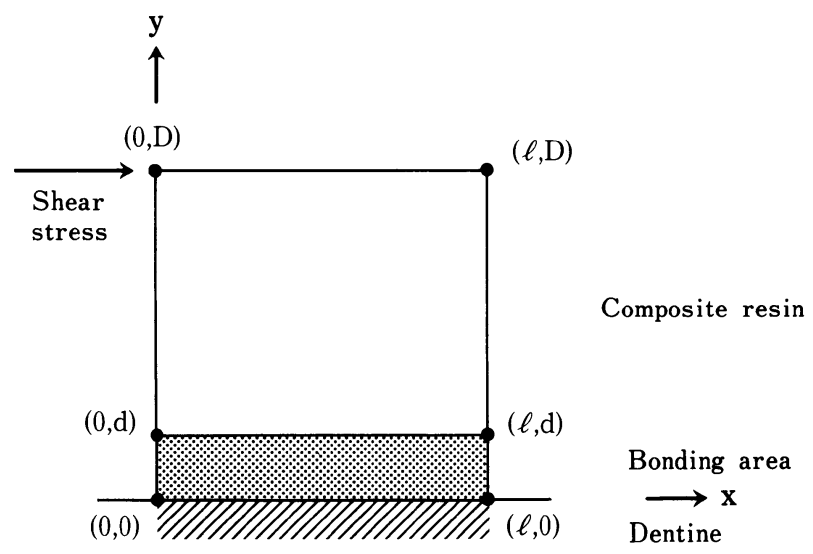

Fig. 1 Schematic diagram (coordinate) of shear bond test.

\& DCS-500, Shimadzu Co, Kyoto, Japan

\&\& DUH-200, Shimadzu Co, Kyoto, Japan

$\S$ EPMA-8705, Shimadzu Co, Kyoto, Japan 


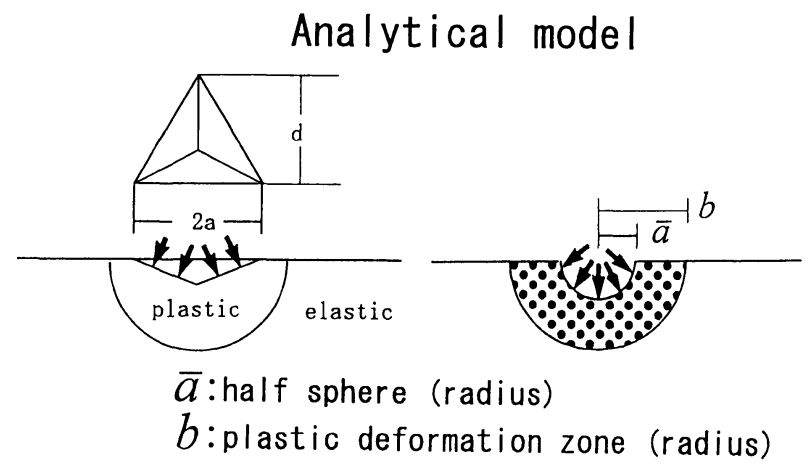

Fig. 2 Analytical model for nano-indentation test to calculate the $(b / 2 a)$-value as a plastic deformation zone. See Appendix 2 for this calculation.

that there arises volumetric strain $\left(\varepsilon_{33} *\right.$; so-called eigenstrain $)$ under the presence of stress release after plastic deformation. The indented area measured by nano-indentation testing was converted to a spherical indented surface (radius of $\bar{a}$ ) under the assumption that the indented area was equal to the area of spherical surface $(\overline{\mathrm{a}}=0.420 \mathrm{a}$ in equation (6) of Appendix 2). The (b/2a)-value to estimate a plastic deformation zone in bonding area is described in equation (7) (Appendix 2).

\section{RESULTS}

\section{Shear bond test}

Table 1 indicates shear bond strengths and bonding area thicknesses of the dentine bonding systems used, showing widely varied strength values of 4.0 to $21.0 \mathrm{MPa}$ and bonding area thickness of 20 to $120 \mu \mathrm{m}$ observed by scanning electron microscopy in a manner similar to that described by Wakasa and Yamaki ${ }^{13}$. Based on these observations, bonding area thickness values of 1,10 , and $100 \mu \mathrm{m}$ were used in this calculation model.

Nano-indentation test

Fig. 3 and 4 show examples of load/indentation depth curves at nano-indentation testing for sample code $B$ and $C$, which were repeated nine times between 1 and $6 \mathrm{mN}$ after loading to $6 \mathrm{mN}$. A plastic deformation zone after nano-indentation to a certain load is illustrated, as indicated schematically in Fig. 2. The load after nano-indentation testing to indentation depth, that is, $d P / d h$, was obtained because of internal stress in the plastic deformation zone after elastic/plastic deformation. From this result, the calculation model was supposed to yield $E / H_{D}$ ( $E$, elasticity of bonding area; $H_{D}$, hardness) and $\mathrm{b} / 2 \mathrm{a}$ values to represent the zone size of the plastic deformation.

Analytical results

Fig. 5 shows average stress along the dentine/adhesive resin interface with respect to interfacial stress, with the thickness of the bonding area $(1,10,100 \mu \mathrm{m})$, and the increased values of average stress obtained by $E_{R} / E=10\left(E_{R}\right.$, elasticity of composite resin; $E=10^{3}$ 
Table 1 Shear bond strength and bond area thickness in dentine bonding systems

\begin{tabular}{ccc}
\hline Code & $\begin{array}{c}\text { Shear bond strength } \\
(\mathrm{MPa})\end{array}$ & $\begin{array}{c}\text { Bond area thickness } \\
(\mu \mathrm{m})\end{array}$ \\
\hline A & $6.8(3.4)$ & $20(5)$ \\
B & $6.1(2.6)$ & $115(10)$ \\
C & $4.5(1.4)$ & $90(7)$ \\
D & $7.5(4.0)$ & $26(4)$ \\
E & $21.0(5.2)$ & $40(15)$ \\
F & $4.0(2.1)$ & $120(25)$ \\
\hline
\end{tabular}

Mean (standard deviation)

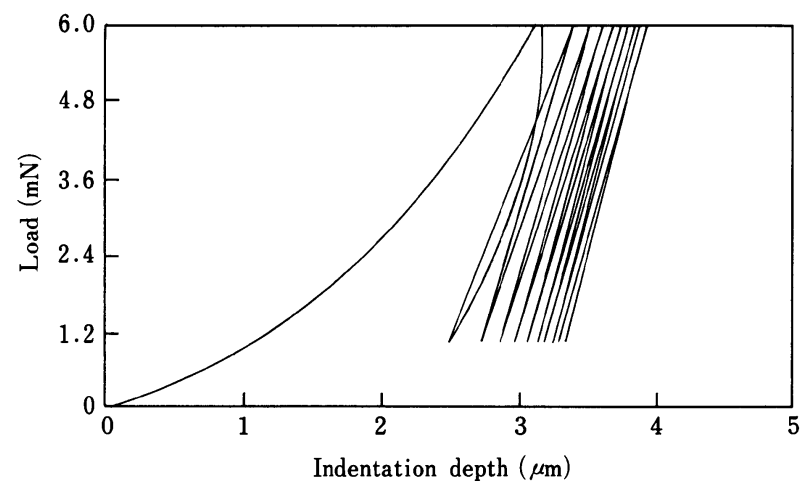

Fig. 3 Example; Load/indentation depth curve for code B.

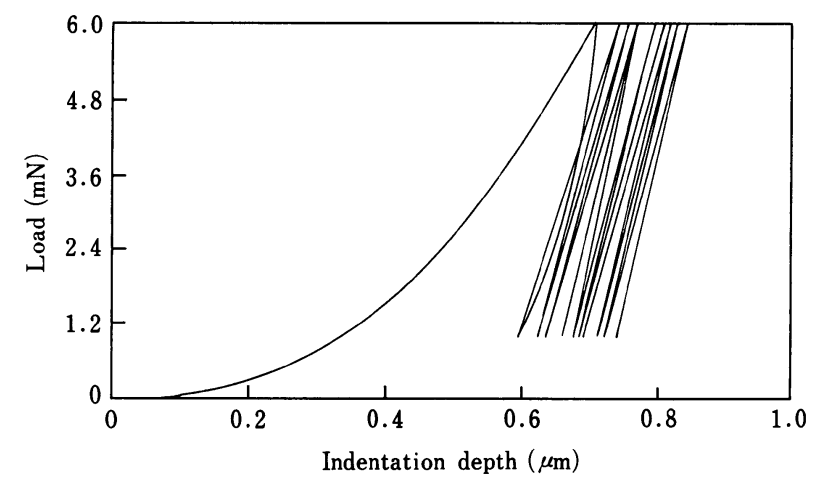

Fig. 4 Example; Load/indentation depth curve for code C.

$\mathrm{MPa}$ ) with interfacial stress of $10,20,50$, and $100 \mathrm{MPa}$ at applied strain $=0.01$. Fig. 6 shows a change of average stress with increasing elasticity values of the bonding area from $10^{2}$ to $5 \times 10^{3} \mathrm{MPa}$ at interfacial stress $=10,20,50$ and $100 \mathrm{MPa}$, with average stress values increasing with increasing elasticity values of the bonding area. These results show that average stress along the dentine/adhesive resin interface is affected by the elasticity of bonding area. 


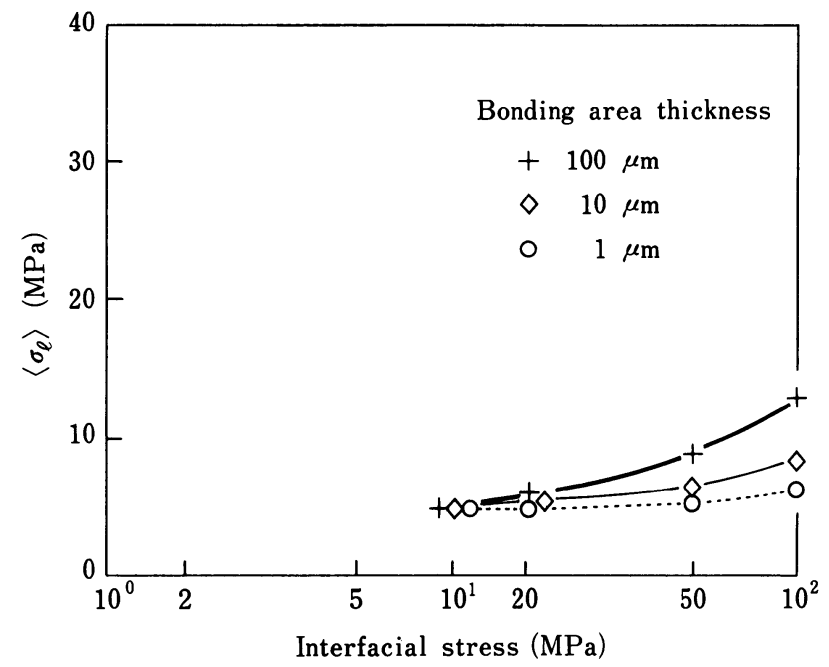

Fig. 5 Change in average stress values with increased interfacial stress at bonding area thicknesses of 1,10 , and $100 \mu \mathrm{m}$.

Solid line (bold): Bonding area thickness $=100 \mu \mathrm{m}$. Solid line (thin): Bonding area thickness $=10 \mu \mathrm{m}$. Dotted line: Bonding area thickness $=1 \mu \mathrm{m}$.

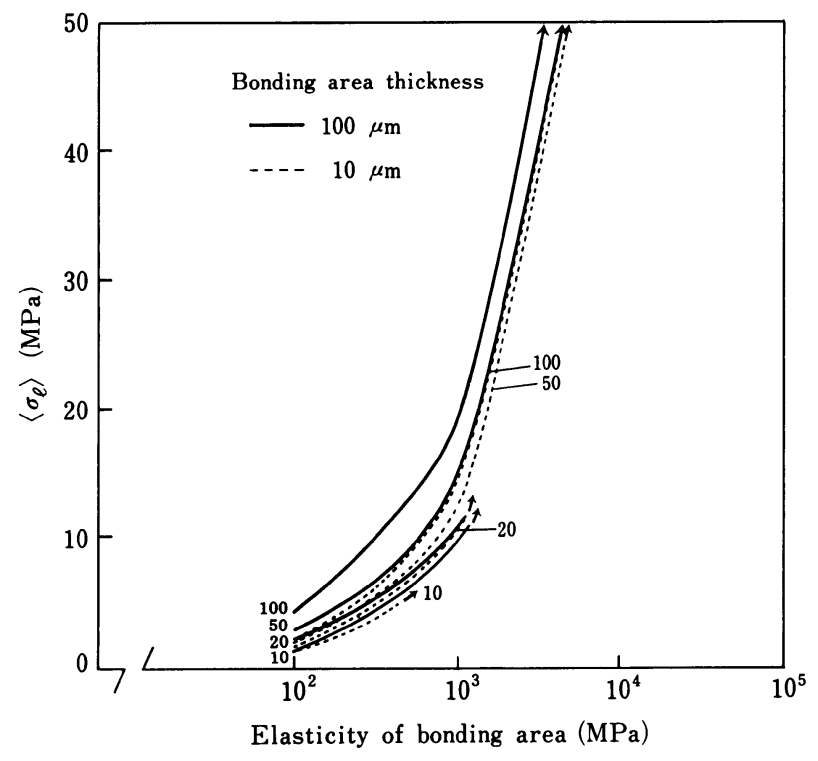

Fig. 6 Change in average stress values with increased elasticity value of bonding area at bonding area thickness of 10 and $100 \mu \mathrm{m}$. Interfacial stress $=10,20,50$ and $100 \mathrm{MPa}$.

Solid line: Bonding area thickness $=100 \mu \mathrm{m}$.

Dotted line: Bonding area thickness $=10 \mu \mathrm{m}$. 
Thus, to clarify the effect of elasticity on the average stress value, average stress-to- $E e$ ratios with respect to elasticity and thickness of bonding area were calculated (Figs. 7, 8),

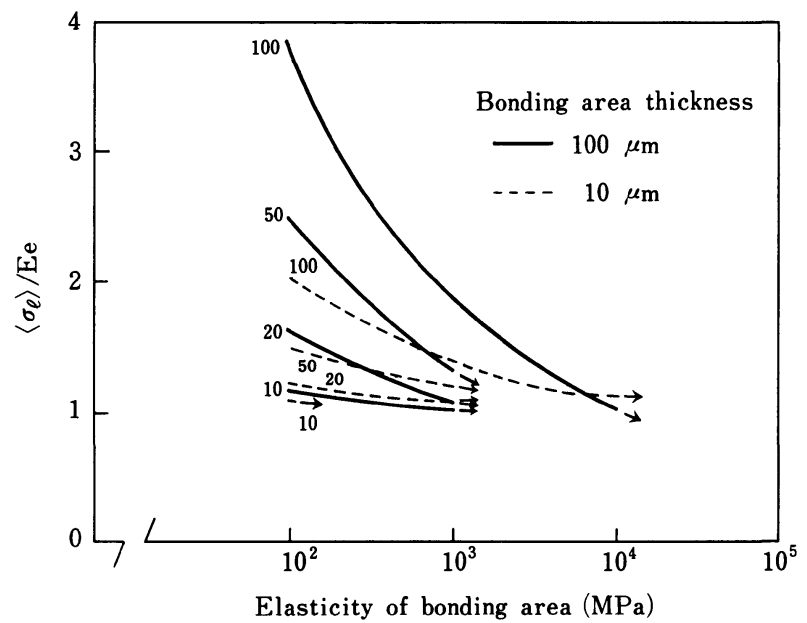

Fig. 7 Relation of elasticity of bonding area and ratio of average stress $/ E e$ for bonding area thicknesses of 10 and $100 \mu \mathrm{m}$.

Solid line; Bonding area thickness $=100 \mu \mathrm{m}$.

Dotted line; Bonding area thickness $=10 \mu \mathrm{m}$.

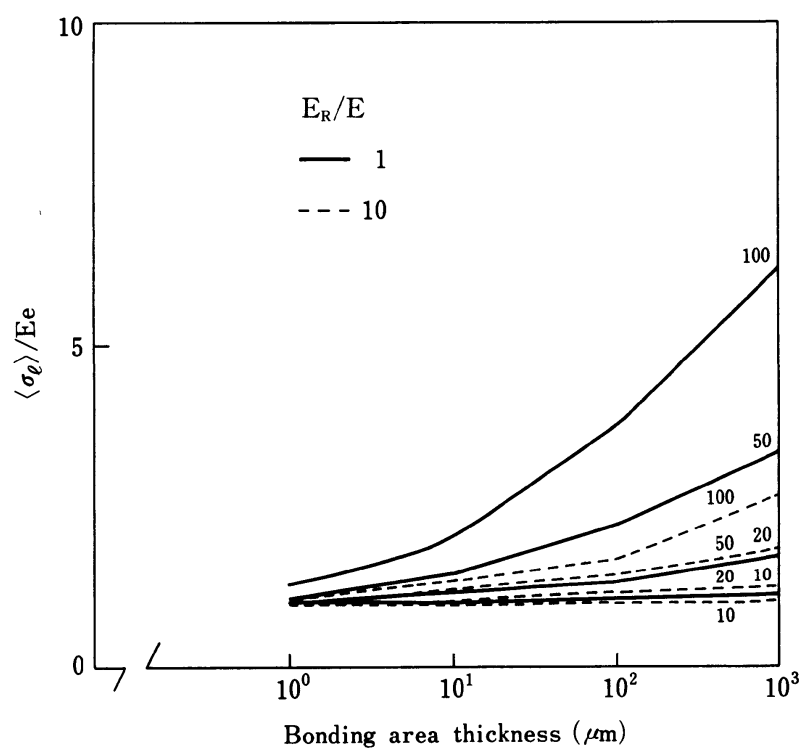

Fig. 8 The relation of bonding area thickness and a ratio of average stress/Ee at $E_{R}$ (composite resin)/ $E$ (bonding area) $=1$ and 10 . The value corresponds to value of interfacial stress $(10,20,50$ and $100 \mathrm{MPa})$.

Solid line : $E_{R} / E=1$.

Dotted line : $E_{R} / E=10$. 
according to equation (I) in Appendix 1. The average stress/Ee ratio decreased with increasing elasticity values from $10^{2}$ to $10^{4} \mathrm{MPa}$ at each value of interfacial stress (Fig. 7). The ratio increased with increasing values of $10^{\circ}, 10^{1}, 10^{2}$ and $10^{3} \mu \mathrm{m}$ (thickness of bonding area) for interfacial stress $=10,20,50$ and $100 \mathrm{MPa}$ at each of $E_{R} / E\left(1,10 ; E=10^{3} \mathrm{MPa}\right)(\mathrm{Fig}$. 8). These results show that the magnitude of average stress might be affected by interfacial stress between the adhesive resin and the dentine within the bonding area. Table 2 indicates the ratio of average stress-to $-E e$ at each value of interfacial stress $(10,20,50$ and $100 \mathrm{MPa})$ at strain $=0.01$ during the shear bond test, showing an increasing tendency toward interfacial stress. Table 3 indicates $d P / d h$ values at $\mathrm{a}=\mathrm{b}$ and $\mathrm{a}=3 \mathrm{~b}$ for each value of elasticity of bonding area at indentation depth $\left(10^{2}\right.$ to $\left.5 \times 10^{4} \mathrm{~nm}\right)$, showing that the $d P / d h$ values increased with indentation depth, that is, associated with plastic deformation. Using the elasticity values of the interdiffusion zone obtained by Meerbeek et al. ${ }^{9)}$, which ranged from approximately $10^{4}$ to $10^{5} \mathrm{MPa}$, plastic deformation zone sizes were estimated to be 3a. Figs. 9 and Table 4 show, respectively, the $(\mathrm{b} / \overline{\mathrm{a}})$ and $(\mathrm{b} / 2 \mathrm{a})$ values with respect to $E / H_{D}$ (a range of $10^{\circ}$ to $\left.10^{4}\right)$ and the changes in elasticity value $(E)$ at each $(\mathrm{b} / 2 \mathrm{a})$ value $(1,2$ and 3$)$. The values of $(\mathrm{b} / \overline{\mathrm{a}})$ and $(\mathrm{b} / 2 \mathrm{a})$ were related to increased values of $E / H_{D}$, showing that bonding areas of dentine bonding systems could be divided into two groups based on the magnitudes of their elasticity values.

Table 2 The ratio of average stress-to- $E$ (elasticity) $e$ (strain) in the bonding area at interfacial stress values of $10,20,50$ and $100 \mathrm{MPa}$ for the change of bonding area thicknesses (10 and $100 \mu \mathrm{m})$

\begin{tabular}{ccc}
\hline \multirow{2}{*}{$\begin{array}{c}\text { Interfacial } \\
\text { stress }\end{array}$} & \multicolumn{2}{c}{$\left\langle\sigma_{l}\right\rangle / E e$} \\
\cline { 2 - 3 }$(\mathrm{MPa})$ & Bonding area thickness $(\mu \mathrm{m})$ \\
& 10 & 100 \\
\hline 10 & 1.0 & 1.0 \\
20 & 1.1 & 1.3 \\
50 & 1.5 & 2.2 \\
100 & 2.0 & 3.7 \\
\hline
\end{tabular}

Table $3 d P / d h$ values at different elasticity values $\left(10^{3}, 10^{4}\right.$ and $\left.10^{5} \mathrm{MPa}\right)$ and indentation depths $=10^{2}, 10^{3}, 10^{4}$ and $5 \times 10^{4} \mathrm{~nm}$. At $\mathrm{a}=\mathrm{b}$ and $\mathrm{a}=3 \mathrm{~b}, d P / d h$ values were calculated according to eduation (5) in Appendix 2. See Fig. 2 for key.

\begin{tabular}{|c|c|c|c|c|c|c|}
\hline \multirow[t]{4}{*}{ Depth (nm) } & \multicolumn{6}{|c|}{$d P / d h(\mathrm{~N} / \mathrm{m})$} \\
\hline & \multicolumn{6}{|c|}{ Elasticity of bonding area (MPa) } \\
\hline & \multicolumn{2}{|c|}{$10^{3}$} & \multicolumn{2}{|c|}{$10^{4}$} & \multicolumn{2}{|c|}{$10^{5}$} \\
\hline & $\mathrm{b}$ & $3 \mathrm{~b}$ & $\mathrm{~b}$ & $3 \mathrm{~b}$ & $\mathrm{~b}$ & $3 b$ \\
\hline $10^{2}$ & $6 \times 10^{2}$ & $2 \times 10$ & $6 \times 10^{3}$ & $2 \times 10^{2}$ & $6 \times 10^{4}$ & $2 \times 10^{3}$ \\
\hline $10^{3}$ & $6 \times 10^{3}$ & $2 \times 10^{2}$ & $6 \times 10^{4}$ & $2 \times 10^{3}$ & $6 \times 10^{5}$ & $2 \times 10^{4}$ \\
\hline $10^{4}$ & $6 \times 10^{4}$ & $2 \times 10^{3}$ & $6 \times 10^{5}$ & $2 \times 10^{4}$ & $6 \times 10^{6}$ & $2 \times 10^{5}$ \\
\hline $5 \times 10^{4}$ & $3 \times 10^{5}$ & $8 \times 10^{4}$ & $3 \times 10^{6}$ & $8 \times 10^{5}$ & $3 \times 10^{7}$ & $8 \times 10^{6}$ \\
\hline
\end{tabular}

At $\mathrm{a}=\mathrm{b}$ and $\mathrm{a}=3 \mathrm{~b}$ for plastic deformation zone size 


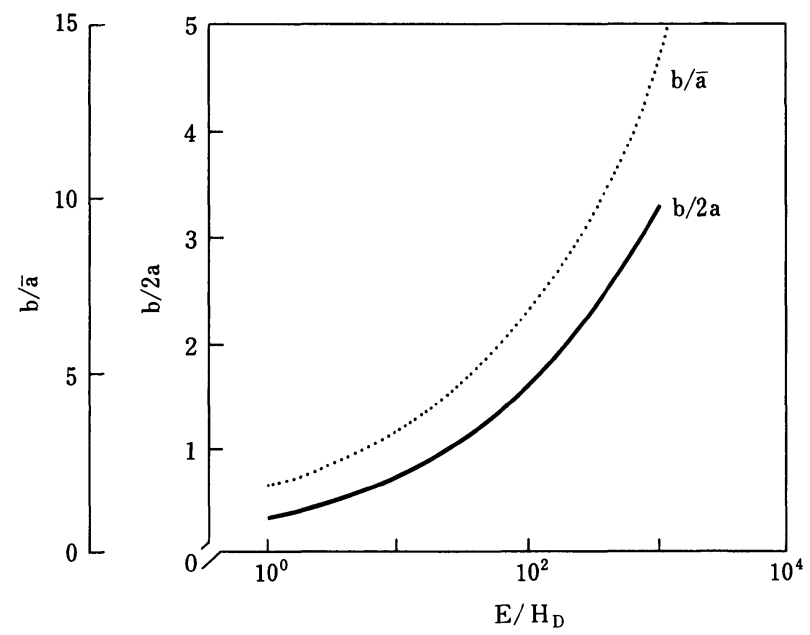

Fig. 9 The relation of $E$ (elasticity of bonding area) $/ H_{D}$ (hardness of bonding area) and $\mathrm{b} / \overline{\mathrm{a}}$ or $\mathrm{b} / 2 \mathrm{a}$.

Solid line; $\mathrm{b} / 2 \mathrm{a}$.

Dotted line; $\mathrm{b} / \overline{\mathrm{a}}$.

Table 4 The estimated value of elasticity of bonding area of $\mathrm{b} / 2 \mathrm{a}$ values of 1,2 , and 3 for dentine bonding systems investigated (code $\mathrm{A}$ to $\mathrm{F}$ )

\begin{tabular}{cccc}
\hline & \multicolumn{3}{c}{$\begin{array}{c}\text { Elasticity } \\
(\mathrm{MPa})\end{array}$} \\
\cline { 2 - 4 } Code & \multicolumn{3}{c}{$\mathrm{b} / 2 \mathrm{a}$} \\
& 1 & 2 & 3 \\
\hline $\mathrm{A}$ & $7 \times 10^{2}$ & $5 \times 10^{3}$ & $1 \times 10^{4}$ \\
$\mathrm{~B}$ & $8 \times 10^{2}$ & $7 \times 10^{3}$ & $2 \times 10^{4}$ \\
$\mathrm{C}$ & $2 \times 10^{4}$ & $2 \times 10^{5}$ & $6 \times 10^{5}$ \\
$\mathrm{D}$ & $9 \times 10^{3}$ & $5 \times 10^{4}$ & $2 \times 10^{5}$ \\
$\mathrm{E}$ & $1 \times 10^{3}$ & $8 \times 10^{3}$ & $4 \times 10^{4}$ \\
F & $1 \times 10^{4}$ & $7 \times 10^{4}$ & $3 \times 10^{5}$ \\
\hline
\end{tabular}

\section{DISCUSSION}

This study examined current dentine bonding systems using respective resin composites. Based on shear bond testing and nano-indentation testing, calculation models and equations were proposed to estimate a) average stress along the dentine/adhesive resin interface (Fig. $1)$; and b) a plastic deformation zone size related to the elasticity-to-hardness ratio $\left(E / H_{D}\right)$ in the bonding area (Fig. 2).

Braem et al. ${ }^{18)}$ reported that low-viscosity resin with about $10^{4} \mathrm{MPa}$ was effective in preventing a separation of the dentine/resin interface. As Nakabayashi et al ${ }^{8)}$ demonstrat 
ed, resin-based adhesives shrink toward the point where they begin curing. 4-META/MMATBB system shrinks toward the tissue, and BPO-amines and visible light-cured adhesives tend to shrink away from the dentine surface. Based on these experiments, we studied theoretically the behavior of polymerized adhesives (bonding area) on the hybrid layer.

As suggested by Braem et $a l .{ }^{18)}$, interfacial stress at the dentine/resin interface is very important in analysis of fracture processes during shear or tensile bond testing. However, it is difficult to measure the magnitude of interfacial stress. In nano-indentation test, the plastic deformation zone size of the bonding area, as examined, depended upon elasticity of the bonding area $(E)$ as well as the $E$ (elasticity) $/ H_{D}$ (hardness) ratio for each dentine bonding system. It is thus possible to estimate average stress on the bonding area at bond testing and to clarify the effect of estimated interfacial stress (a range of 10 to $100 \mathrm{MPa}$ ), as suggested by Van Noort et al. ${ }^{12)}$ and Wakasa and Yamaki ${ }^{13)}$, on average strength values. The bond strength at each depth of bovine dentine gave varied widely as a function of depth ${ }^{1-6,19)}$. The macroscopic mode of failure appears to be adhesive in nature which indicates failure at the dentine/composite interface ${ }^{6)}$, because the strength values range from 1 to $23 \mathrm{MPa}^{20,21)}$. Eick et al. ${ }^{21)}$ proposed a three-level clasification scheme based on shear bond strength ; 5 to $7 \mathrm{MPa}$ (category I ), 8 to $14 \mathrm{MPa}$ (category II) and up to $20 \mathrm{MPa}$ (category III), whereas Triolo $\mathrm{Jr}$ et $a l .{ }^{22)}$ reported that the bond strength values were $8 \mathrm{MPa}$ or less. McGuckin et al. ${ }^{23)}$ reported that bond strength varied inversely with the dentine's proximity to the pulp. To clarify the nature of the bonding area as observed by repeated experiments ${ }^{1-9)}$, the present experiment is of importance in calculating theoretically average stress and elastic/plastic deformation behaviour of the bonding area formed during bonding. Moreover, as described in experimental results showing that bonding area thickness affects bond strength and that elssticity values change according to the nature of the bonding area or interdiffusion zone between dentine and composite resin ${ }^{9,10,12,13,16)}$, theoretical attempts, based on the stress behaviour during bond and nano-indentation tests, are needed to clarify their estimates.

The plastic deformation zone size of the bonding area changed with increased $E / H_{D}$ values of dentine bonding systems used (Fig. 9), and the elasticity value of the bonding area depended strongly upon the zone size after elastic/plastic deformation (Table 4). At the bonding areas analyzed by nano-indentation testing, average strengths estimated using these results were lower than values obtained during a bond test (Fig. 5). The change of average stress in the bonding areas with interfacial stress was related to thickness of the bonding area during shear bond test :

1. Average stress was very small for each magnitude of interfacial stress, 10, 2050 and $100 \mathrm{MPa}$ at each bonding area thickness $(1,10$, and $100 \mu \mathrm{m})$.

2. Average stress increased with increased elasticity values, $10^{2}$ to $5 \times 10^{3} \mathrm{MPa}$ for each interfacial stress $=10,20,50$ and $100 \mathrm{MPa}$ (thickness of bonding area $=10,100 \mu \mathrm{m}$ ).

During the dentine bonding test, bonding area showed changes in average stress-to- $E e$ ratio of various bonding area elasticity values (Figs. 7,8$)$ :

1. For thickness of bonding area $(10$ and $100 \mu \mathrm{m})$, the decreased change of the ratio with increased elasticity values was analyzed.

2. The greater $E_{R} / E$ ratio (10) showed a smaller average stress/Ee ratio at each thickness of bonding area, as compared with that at $E_{R} / E=1$. 
To examine the stress behaviour of the bonding area during shear bond testing, the average stress in bonding area was calculated when applied to dentine/resin interface as the composite according to our calculation model (Appendix 1). Average stress values changed with elasticity of the bonding area $(E)$, thickness of the bonding area $(d)$ and interfacial stress related to applied stress. Average stress in the bonding area increased with the increased elasticity values $10^{2}$ to $5 \times 10^{3} \mathrm{MPa}$ as compared with $100 \mu \mathrm{m}$ thickness than in that with 10 $\mu \mathrm{m})$, and thus the nature of adhesive resin of bonding area as a polymerized site is important in evaluating bond strength. We may predict fracture sites along the dentine/adhesive resin and adhesive resin/composite resin interfaces, if it is possible to determine fracture strength when average stress in the bonding area reaches to a certain level of yield stress. These models are effective in calculating the magnitudes of average stress and the plastic deformation zone in relation to fracture mechanisms in the bonding area.

\section{CONCLUSION}

In the dentine bonding systems investigated, average stress and nano-indentation behaviour in the bonding area were analyzed in relation to bond strength to bovine dentine. It was found that average stress increased with interfacial stress for each of bonding area thickness $(1,10$, and $100 \mu \mathrm{m})$. In calculation models, elasticity, interfacial (dentine/adhesive resin) stress, and bonding area thickness were important in the estimation of average stress. This study also compared theoretical values of elastic/plastic indentation zones through nanoindentation analysis of bonding areas with respect to changes in elasticity.

\section{ACKNOWLEDGMENTS}

The authors express deep thanks and appreciation to the Central Research Group at the Hiroshima University School of Dentistry for granting preliminary use of the Biomaterial Combined Analysis System. This study was supported in part by a Grant-in-Aid from the Ministry of Education, Science, Sports, and Culture, Japan, (C) 07672112.

\section{APPENDIX 1}

The equilibrium of stress along the $\mathrm{x}$-axis can be expressed as

$$
d\left(\sigma_{l}\right) / d x=c\left(d_{u}-d_{v}\right)
$$

where $\mathrm{c}$ is an unknown constant value, and $d_{u}-d_{v}$ the displacement caused by interfacial stress $\sigma_{0}$ between dentine and adhesive resin in the bonding area.

In the bonding area the stress, $\sigma_{l}$ can be estimated as $E\left(d\left(d_{u}\right) / d x\right)$, and the stress in equation (A) can be expressed as

$$
\sigma_{l}=E e+C_{1} \cosh (A x)+C_{2} \sinh (x)
$$

where $A^{2}=c / E, C_{1}, C_{2}=$ stress-dependent factors.

The boundary conditions for determining unknown integration values in equation (B) are 
assumed to be in the following equations,

$$
\begin{aligned}
& \sigma_{l}=\sigma_{0} \text { at } x=l \\
& d\left(\sigma_{l}\right) / d x=0 \text { at } x=0
\end{aligned}
$$

The stress in the bonding area can be estimated as

$$
\sigma_{l}=E e[1+(B-1) \cosh (A x) / \cosh (A l)]
$$

where $B=\sigma_{0} / E e$.

The displacement along the $\mathrm{x}$-axis can be calculated as

$$
\gamma=\tau / \mu=\left(\tau_{0} / \mu\right)(d / x)
$$

At an arbitrary point $\mathrm{r},\left(d_{v}-d_{u}\right)$ displacement can be given as

$$
d_{v}-d_{u}=\frac{\tau_{0} l}{\mu} \int_{d}^{D} \frac{1}{r} d r=\frac{\tau_{0} l}{\mu} \ln (D / d)
$$

Thus, $A$ can be solved as

$$
A=(2 / D d)^{\frac{1}{2}}(\mu / E)^{\frac{1}{2}}(1 / \ln (D / d))^{\frac{1}{2}}
$$

Then, the average stress in the bonding area can be determined as

$$
\left\langle\sigma_{l}\right\rangle=\frac{1}{l} \int_{0}^{l} \sigma_{l} d x=E e[1+(B-1) \tanh (A l) / A l]
$$

\section{APPENDIX 2}

After a nano-indentation test, internal stress occurred as indicated in Fig. 3, and the value of $\sigma_{33} *$ can be estimated when $\varepsilon_{11} *$ and $\varepsilon_{22}{ }^{*}=0$ and only $\varepsilon_{33}{ }^{*}$ occurs, according to the concept introduced by Mori and Tanaka ${ }^{17)}$, as

$$
\sigma_{33} *=-\left\{8 E / 15\left(1-\nu^{2}\right)\right\} \varepsilon_{33} *
$$

where $E=$ elasticity of bonding area and $\nu=$ poisson ratio.

For the calculation model of Fig. 2, load and internal strain can be calculated as

$$
\begin{aligned}
& P=-2 \pi(\bar{a})^{2} \sigma_{33}{ }^{*} \\
& \varepsilon_{33} *=\delta V / V
\end{aligned}
$$

where $\delta V=\frac{1}{3}\left(\frac{\sqrt{3}}{4} d^{2}\right) h, V=\frac{1}{2}\left(\frac{4}{3} \pi b^{3}\right)$.

A substitution of equations (1) and (3) into (2) leads to the formula to predict load

$$
P=K \frac{E}{1-\nu^{2}}\left(\frac{1}{b}\right)^{3} h^{5}
$$

where $K$ is a constant value.

The change of load to indentation depth $(h)$ can be calculated as

$$
\frac{d P}{d h}=K^{\prime} \frac{E}{1-\nu^{2}}\left(\frac{1}{b}\right)^{3} h^{4}
$$


where $K^{\prime}$ is a constant value.

During a nano-indentation test, $H_{D}$ can be calculated as

$$
H_{\mathrm{D}}=0.37081 P / h^{2}
$$

where $h=0.269 a$

$$
\bar{a}=0.420 a .
$$

A substitution of (4) into (6) leads to the formula to predict plastic deformation zone size, $b / 2 a$

$$
\frac{b}{2 a}=K^{\prime \prime}\left(\frac{1}{1-\nu^{2}}\right)^{\frac{1}{3}}\left(\frac{E}{H_{D}}\right)^{\frac{1}{3}}
$$

where $K^{\prime \prime}$ is a constant value.

\section{REFERENCES}

1) Pashley, E. L., Tao, L., Mackert, J. R. and Pashley, D. H.: Comparison of in vivo versus in vitro bonding of composite resin to the dentin of canine teeth, J Dent Res 67 (3) : 467-470, 1988.

2) Tagami, J., Tao, L. and Pashley, D. H.: Correlation among dentin depth, permeability and bond strength of adhesive resins, Dent Mater 6: 45-50, 1990.

3) Gray, S. and Burgess, J.: In vivo and in vitro comparison of two dentin bonding agents, Dent Mater 7: 161-165, 1991.

4) Nakabayashi, N., Ashizawa, M. and Nakamura, M. : Identification of a resin dentin hybrid layer in vital human dentin created in vivo: durable bonding to vital dentin, Quint Int 23 : 135-141, 1992.

5) Tam, L. E. and Pillar, R. M. : Fracture toughness of dentin/resin composite adhesive interfaces, $J$ Dent Res : 72 (5) : 953-959, 1993.

6) Pashley, E. L., Tao, L., Matthews, W. G. and Pashley, D. H. : Bond strengths to superficial, intermediate and deep dentin in vivo four dentin bonding systems, Dent Mater 9: 19-22, 1993.

7) Nakabayashi, N., Kojima, K. and Masuhara, E.: The promotion of adhesion by the infiltration of monomers into tooth substrates, J Biomed Mater Res 16:265-273, 1982.

8) Nakabayashi, N., Nakamura, M. and Yasuda, N.: Hybrid layer as a dentin-bonding mechanism, $J$ Esthetic Dent 3 (4) : 133-138, 1991.

9) Van Meerbeek, B., Inokoshi, S., Braem, M., Lambrechts, P. and Vanherle, G. : Morphological aspects of resin-dentin interdiffusion zone with different dentin adhesive systems, $J$ Dent Res : 71 (8) : 1530 $-1540,1992$.

10) Wakasa, K., Ikeda, K., Yoshida, Y., Nakatsuka, A., Yamaki, M. and Matsui, A. : J J Dent Mater 14 Special 25: 182-183, 1995. (in Japanese)

11) Pashley, D. H.: The effects of acid etching on the pulpodentin complex, Oper Dent $17: 229-242,1992$.

12) Van Noort, R. and Northeast, S. E. : A critique of bond strength measurements, $J$ Dent 17: 61-67, 1989.

13) Wakasa, K. and Yamaki, M.: Bond strength between dentine and restorative resins-Calculation model, Dentistry in Japan 31 : 81-84, 1994.

14) Wang, C. T. and Pillar, R. M. : Short-rod elastic-plastic fracture toughness test using miniature specimens, J Mater Sci 24 : 2391-2400, 1989.

15) Van Noort, R., Cardew, G. E., Howard, I. C., and Noroozi, S. : The effect of local interfacial geometry on the measurement of the tensile bond strength to dentin, J Dent Res : 70 (1) : 61-67, 1991.

16) Van Meerbeek, B., Braem, M., Lambrechts, P. and Vanherle, G. : Assessment by nano-indentation of the hardness and elasticity of the resin-dentin bonding area, J Dent Res 72 (10) : 1434-1442, 1994.

17) Mori, T. and Tanaka, K.: Average stress in matrix and average elastic energy of materials with misfitting inclusions, Acta Metallurgica 21, 571-574, 1973.

18) Braem, M., Lambrechts, P., Van Doren, V. and Vanherle, G. : The impact of composite structure on 
its elastic response, $J$ Dent Res 65 (4): 648-653, 1986.

19) Tagami, J., Tao, L. and Pashley, D. H.: Correlation among dentin depth, permeability, and bond strength of adhesive resins, Dent Mater 6: 45-50, 1990.

20) McCabe, J. F. and Rusby, S.: Dentine bonding agents-characteristic bond strength as a function of dentine depth, $J$ Dent 20 : 225-230, 1992.

21) Eick, J. D., Cobb, C. M., Chappel, R. P., Spencer, P. and Robinson, S. J.: The dentinal surface : Its influence on dentinal adhesion. Part I, Quint Int 22: 967-977, 1991.

22) Triolo Jr., P. T. and Swift Jr., E. J. : Shear bond strengths of ten dentin adhesive systems, Dent Mater 8: 370-374, 1992.

23) McGuckin, R. S., Tao, L., Thompson, W. O. and Pashley, D. H. : Shear bond strength of Scotchbond in vivo, Dent Mater 7 : 50-53, 1991. 
3-メタクリロキシプロピールシリルトリイソシアナー トと 3-メルカプトプロピールトリメトキシランの混合 シラン処理剤を陶歯, 貴金属合金および非貴金属合金の 接着プライマーとして用いた。サーマルサイクル試験 1,000 回後, 陶歯, 銀合金およびステンレススチールに
対する接着強さは良好であった。このときの陶歯の破断 面の状態は初期の状態と同じであり，2本が陶歯, 残り はレジンの凝集破壊であった，しかし，コバルトクロム 合金には効果は認められなかった。

\section{歯科用アマルガムの初期圧縮強さと合金相の生成}

\section{Chatcharee Suchatlampong, 後藤真一 ${ }^{1}$, 小倉英夫 ${ }^{1}$}

歯科用アマルガムの初期強さ特性を合金相の生成と関 連づけて調べるために，5種のアマルガムについて 1 時 間後, 6 時間後, 24 時間後, および 7 日後の圧縮強さを 測定し，同一時間後に各アマルガムの X 線回折を行っ た. 試験したアマルガムはいずれも 24 時間後には 7 日 後の圧縮強さの約 $90 \%$ ，または，それ以上に達した。し かし, 1 時間後から 24 時間後までの初期圧縮強さの増加 はアマルガムの種類によって異なっていた，試験した 5
種のうち, 2 種のアマルガムは 6 時間後に 7 日後の圧縮 強さの約 $90 \%$ に達した. 7 日後の圧縮強さに対する初期 圧縮強さの比と $\gamma_{1}$ 相の回折強度比 ( 7 日後の回折強度に 対する 1 時間後, 6 時間後ならびに 24 時間後の回折強 度の比）との間には有意な相関が認められ，初期圧縮強 さの増加は主として $\gamma_{1}$ 相の生成に依存することが示さ れた。

\section{象牙質接着システムにおける接着領域の 平均応力および塑性域の計算モデル}

若狹邦男, 山木昌雄, 松井 昌 ${ }^{1}$

広島大学歯学部歯科理工学講座

1葵歯学研究所

本研究では, 象牙質接着システムにおいてコンポジッ トレジンと重合する接着場所としての接着領域 (bonding area) での剪断接着試験による平均応力および nano-indentation 試験で求めた変形挙動を評価するこ ととした. はじめに, 接着領域内平均応力は象牙質・接 着レジン界面に沿って計算する。第 2 には, 塑性変形域 の大きさを nano-indentation 試験ののち, 弾性・塑性変 形を呈する領域をモデル化して計算した. その結果, 平
均応力を接着領域の弾性率(E), (コンポジットレジンの 弾性率, $\left.\mathrm{E}_{\mathrm{R}} / \mathrm{E}\right)$ 比抽よび象牙質・接着レジン界面応力に よって表わすことができた. さらに,この接着領域では $\mathrm{B} / \mathrm{H}_{\mathrm{D}}$ (接着領域の硬さ) 比がその接着領域の厚さに依存 することや塑性域の大きさを示す $(b / 2 a)$ 比 (b; 塑性域 の大きさ, $2 \mathrm{a}$; nano-indentation 試験での圧痕長さ)が 接着領域の弾性率の増加とともに大きくなることを明確 に示した. 